\title{
The proprotein convertase furin is required to maintain viability of alveolar rhabdomyosarcoma cells
}

\author{
Patricia Jaaks ${ }^{1}$, Gianmarco Meier ${ }^{1}$, Nagjie Alijaj$^{1}$, Eva Brack ${ }^{1}$, Peter Bode ${ }^{2}$, Ewa \\ Koscielniak ${ }^{3}$, Marco Wachtel ${ }^{1}$, Beat W. Schäfer ${ }^{1}$, Michele Bernasconi ${ }^{1}$ \\ ${ }^{1}$ Department of Oncology and Children's Research Center, University Children's Hospital Zurich, Zurich, Switzerland \\ ${ }^{2}$ Department of Surgical Pathology, University Hospital Zurich, Zurich, Switzerland \\ ${ }^{3}$ Department of Oncology/Hematology/Immunology, Olgahospital, Klinikum Stuttgart, Stuttgart, Germany \\ Correspondence to: Michele Bernasconi, email: michele.bernasconi@kispi.uzh.ch \\ Keywords: furin, proprotein convertases, rhabdomyosarcoma, apoptosis, IGFIR \\ Received: February 10, $2016 \quad$ Accepted: August 09, $2016 \quad$ Published: August 27, 2016
}

ABSTRACT

Rhabdomyosarcoma (RMS) is the most common soft tissue sarcoma in children. Success of current therapies is still limited and outcome is particularly poor for metastatic alveolar rhabdomyosarcoma (aRMS). We previously identified the proprotein convertase furin as potential target for specific drug delivery with RMShoming peptides. Furin is a protease that converts inactive precursor proteins into bioactive proteins and peptides. In this study, we investigate the biological role of furin in aRMS progression in vitro and in vivo. Furin expression was confirmed in over $86 \%$ RMS biopsies in a tissue microarray $(n=89)$. Inducible furin silencing in vitro led to significant impairment of cell viability and proliferation in all investigated aRMS cell lines, but not in MRC5 fibroblasts. Furthermore, the aRMS cell lines Rh3 and Rh4 revealed to be very sensitive to furin silencing, undergoing caspase-dependent cell death. Notably, furin silencing in vivo led to complete remission of established Rh4 tumors and to delayed growth in Rh30 tumors. Taken together, these findings identify furin as an important factor for aRMS progression and survival. Thus, we propose furin as a novel therapeutic target for treatment of aRMS.

\section{INTRODUCTION}

Rhabdomyosarcoma (RMS) is the most common pediatric soft tissue sarcoma, representing $5-8 \%$ of all childhood cancers. RMS is subdivided in two main histological subgroups, embryonal (eRMS) and alveolar (aRMS) RMS. aRMS is more aggressive and is associated with a poorer prognosis with a 5-year survival of $48 \%$ [1]. Around $80 \%$ of aRMS tumors harbor the chimeric transcription factor PAX3/7-FOXO1 inducing a specific gene expression signature $[2,3]$. A dominant role of PAX3/7-FOXO1 as oncogenic driver has been suggested $[4,5]$. Despite the dependence of aRMS tumors on PAX3/7-FOXO1 expression, transcription factors in general represent a challenging target.

Thus, many efforts have been made to characterize key pathways driving RMS progression in order to identify targets for novel therapeutic approaches. The insulin-like growth factor 1 receptor (IGF1R) is one among them. IGF1R is a transcriptional target of PAX3-FOXO1 [6] and increased levels of the receptor correlate with poorer outcome in aRMS patients [7]. The ligand of IGF1R, the insulin-like growth factor 2 (IGF-2), is overexpressed in RMS [8] and acts as an autocrine mitogen [9]. Therefore, the IGF1R signaling pathway is a promising target to treat aRMS tumors. Different approaches to disrupt IGF1R signaling in RMS have been investigated: IGF1R antisense RNA [10], IGF1R-specific blocking antibodies [11] and the selective IGF1R inhibitor NVP-AEW541 [12].

Proteolytic processing of precursor proteins by proprotein convertases (PCs) produces a large variety of bioactive proteins, such as growth factors, receptors, enzymes and cell-adhesion molecules. PCs are calciumdependent serine proteases and seven of the nine family members (PC1, PC2, furin, PC4, PC5, paired basic amino acid cleaving enzyme 4 (PACE4) and PC7) process proproteins at basic residues. The other two, SK-1 and PCSK9, cleave after non-basic residues [13]. Enhanced activity of PCs has been associated with pathological conditions like Alzheimer's disease [14] and correlates 
with increased malignancy of certain cancer types such as prostate cancer, colon carcinoma or small cell lung carcinoma [15-17].

Furin was the first identified PC and acts within the constitutive secretory pathway [18]. It processes many cancer-related proteins like IGF1R [16], the vascular endothelial growth factor C (VEGF-C) [19] or the membrane-type 1 matrix metalloprotease (MT1MMP) [20]. Aberrant furin expression is associated with neoplasias like head and neck cancer, breast, lung or colon cancers [21-24]. Upregulation of furin expression and translocation to the plasma membrane under hypoxic conditions are considered to favor invasiveness of cancer cells through enhanced proteolytic activation of MT1MMP and TGF $\beta[25,26]$. Thus, furin is a key activator of proproteins involved in cancer progression and represents a promising target to improve cancer treatment. Furin is endogenously inhibited by its own prodomain that is cleaved in a two-step autocatalytic activation process and the use of the prodomain as furin inhibitor has been proposed [27, 28]. Alternative inhibitory approaches are application of polyarginines [29], nanobodies [30] or $\alpha 1$ antitrypsin Portland (PDX) [31]. However, most if not all proposed inhibitors lack selectivity for furin and are still in early developmental phases.

We previously identified specific RMS homing peptides that bind to the proprotein convertase (PC) furin [32]. Here, we investigate in detail the role of furin in aRMS progression in vitro and in vivo. We use inducible expression of furin specific shRNA to decrease furin expression and activity. Furin silencing resulted in impaired cell viability, caspase-dependent apoptosis and regression of tumors. We further found that furin is expressed in most patient biopsies. Therefore, we propose the proprotein convertases furin as novel target for aRMS therapy.

\section{RESULTS}

\section{Validation of inducible furin silencing in alveolar RMS cells}

In order to simulate specific furin inhibition we generated stable aRMS cell lines with tetracyclinedependent expression of furin shRNA (shFAi and shFEi) or control shRNA (scri) (Figure 1A). Furin silencing was assessed 24-72h after doxycycline (DOX) treatment. Upon DOX treatment furin mRNA was reduced to around 15\% in Rh30 cells (Figure 1B) and to $6.5-25 \%$ in other aRMS cell lines (Supplementary Figure S1A). Subsequently, we analyzed furin protein levels in Rh30 cells by immunoblotting und could confirm that furin protein levels were strongly reduced upon DOX treatment (Figure $1 \mathrm{C})$. To monitor furin activity we analyzed the maturation of a known furin substrate, IGF1R $\beta$. Decrease of furin led to clear reduction of mature IGF1R $\beta$, indicating that furin activity is indeed lowered upon silencing of furin (Figure 1C). mRNA levels of other PCs, examined by qRTPCR after $48 \mathrm{~h}$ of treatment with $25 \mathrm{ng} / \mathrm{mL}$ DOX, were unaffected suggesting that furin silencing was specific and was not compensated for by increased mRNA expression of other PCs (Supplementary Figure S1B). In conclusion, we generated and validated aRMS cell lines with functional furin silencing that is inducible by application of DOX. Furthermore, effects of furin silencing on IGF1R processing and downstream Akt activation upon stimulation with IGF1 could be demonstrated in Rh3 cells (Figure 1D) and to a lesser extent in Rh4 cells (Supplementary Figure S1C). This suggests that activation of the IGF signaling pathway is furin dependent at least in a subset of aRMS cells.

\section{Furin silencing decreases cell viability and proliferation}

Furin processes a variety of substrates, e.g. IGF1R, that support cancer cell viability and proliferation. Thus, we induced furin silencing in four different aRMS cell lines, Rh30, Rh4, CW9019 and Rh3, and assessed cell viability. Cell viability was clearly decreased, as compared to non-treated cells (Figure 2A - Rh30: 27\%, Rh4: 7\%; Supplementary Figure S2A - CW9019: 48\%, Rh3: 19\%). The number of viable adherent cells was reduced up to 5-fold compared to non-treated cells (Figure 2B - Rh30: 23\%, Rh4: 20\%; Supplementary Figure S2B - CW9019: 54\%, Rh3: 23\%). Furthermore, proliferation, examined by BrdU incorporation, was much lower in furin silenced Rh30 and Rh4 cells than in cells expressing control shRNA and went down to $48 \%$ and $15 \%$, respectively (Figure 2C). We also noted a slight toxic effect upon expression of the control shRNA (scri) in all aRMS cell lines (Figure 2A-2C). Since DOX application alone had no effect on viability of aRMS wt cells (data not shown), we assume that this slight effect may be due to high shRNA expression after DOX treatment. Furthermore, we investigated furin silencing in MRC5 fibroblast cells and found that induced silencing of furin had no significant impact on viability of MRC5 fibroblast cells (Figures 2D and $2 \mathrm{E}$ ). Thus, furin activity seems to be a critical factor in viability and proliferation of aRMS cells, whereby a decrease of furin does not alter cell viability of normal fibroblasts.

\section{Reduced furin activity results in caspase- dependent cell death involving mitochondria}

In our initial investigation of aRMS cell viability upon furin silencing we observed that reduced furin activity not only impaired cell viability and proliferation of the cells, but also led to morphological changes and cell death in Rh4 and Rh3 cells. Therefore, we examined the cell cycle distribution of Rh4 and Rh3 cells $72 \mathrm{~h}$ after 
DOX treatment and found a clear increase of cells in sub-G1 phase (Figure 3A - shFAi: 54-62\%, shFEi: 26$32 \%$ ). As a positive control for apoptosis we treated aRMS cells with a combination of $1 \mu \mathrm{M}$ of the IGF1R-inhibitor AEW451 (AEW) and $275 \mathrm{nM}$ of the dual PI3K/mTOR inhibitor BEZ235 (BEZ) for 24h, conditions that induce apoptosis in aRMS cell lines [33]. As expected, treatment with BEZ/AEW led to an increase of cells in sub-G1 phase (Figure 3A - Rh4: 22\%, Rh3: 18\%). To assess the contribution of caspases in cell death induction we treated

A

pRSI inducible shRNA vector

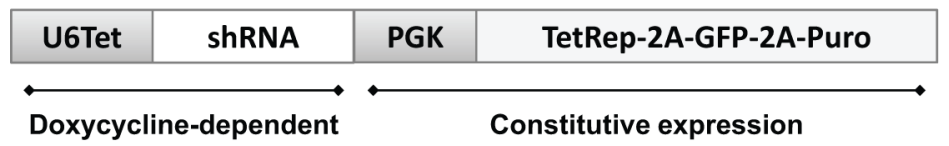
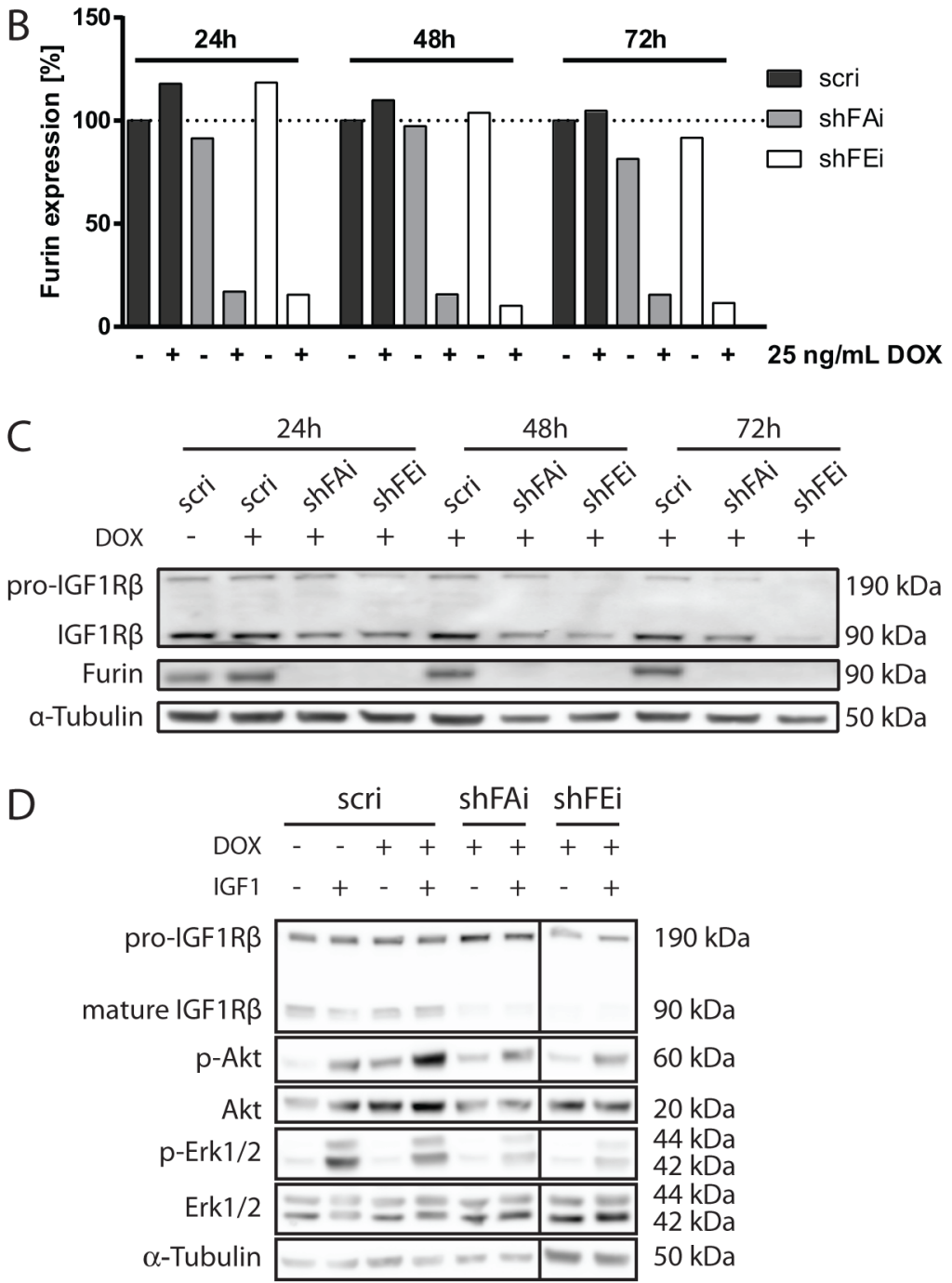

Figure 1: Inducible silencing of furin in alveolar RMS cells. A. Schematic overview of the pRSI vector for inducible shRNA expression. Tet repressor, GFP and puromycin resistance under control of a phosphoglycerate kinase 1 (PGK) promoter are constitutively expressed. The tetracycline dependent promoter (U6Tet) controls expression of shRNA. Rh30 cells transduced with pRSI coding for control (scri) or furin (shFAi, shFEi) shRNAs were treated with $25 \mathrm{ng} / \mathrm{mL}$ doxycycline (DOX). B. Furin mRNA levels were determined in Rh30 cells by qRT-PCR at different time points after DOX addition. Expression levels relative to GAPDH and normalized to non-treated control (scri) cells are shown. The experiments were performed in duplicates. C. Protein expression of furin and its substrate IGF1R $\beta$ were examined in Rh30 cells by immunoblotting $24 \mathrm{~h}, 48 \mathrm{~h}$ and $72 \mathrm{~h}$ post-induction. One representative experiment is shown. D. Rh3 cells were stimulated for $10 \mathrm{~min}$. with $50 \mathrm{ng} / \mathrm{mL}$ IGF1 $48 \mathrm{~h}$ post induction of furin silencing and phosphorylation of IGF signaling pathway mediators Akt and Erk1/2 was examined by immunoblotting. One representative experiment is shown. 
the cells with $100 \mu \mathrm{M}$ of the pan-caspase inhibitor zVAD. Cell cycle profiles of furin silenced or BEZ/AEW treated cells were restored in the presence of zVAD similar to non-treated levels, indicating that induced cell death is caspase dependent (Figure 3A).
To further elucidate the mechanism underlying cell death, we analyzed cleavage of caspase- 7 and -9 and PARP by immunoblotting. In Rh4 and Rh3 cells, both caspases as well as PARP were cleaved upon furin silencing and BEZ/AEW treatment, confirming apoptosis induction.
A

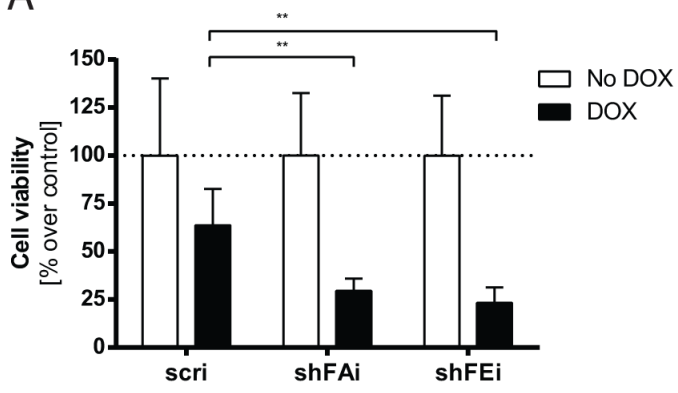

B

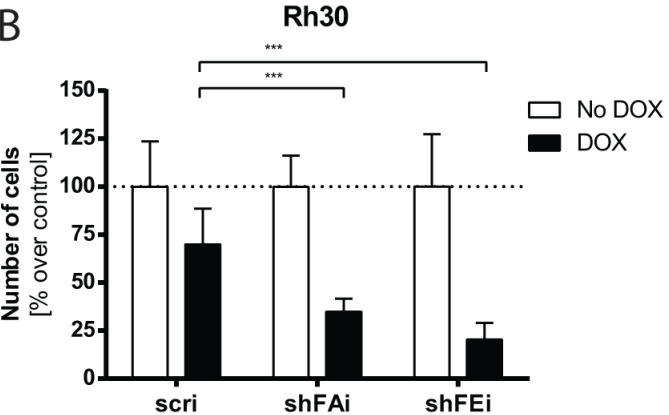

C
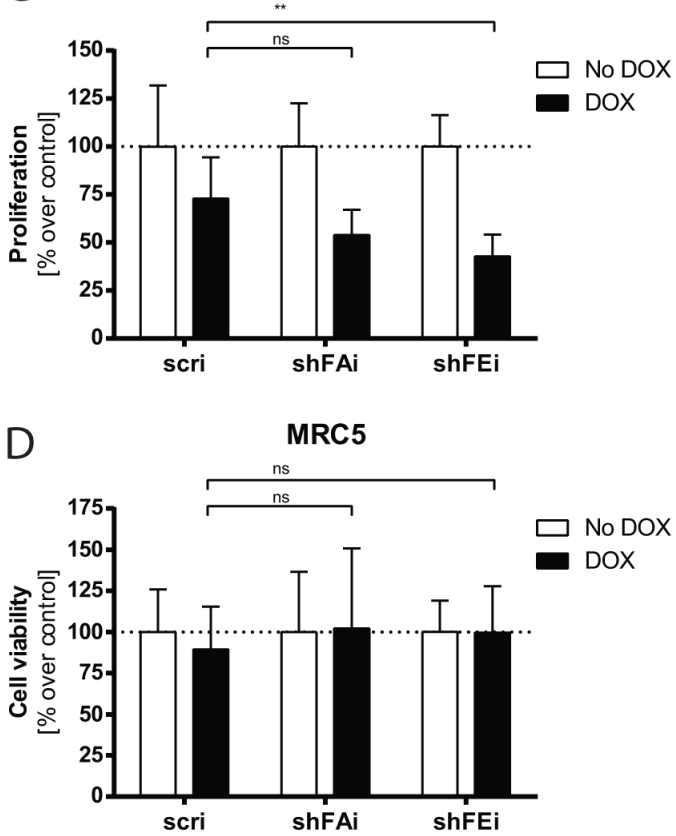
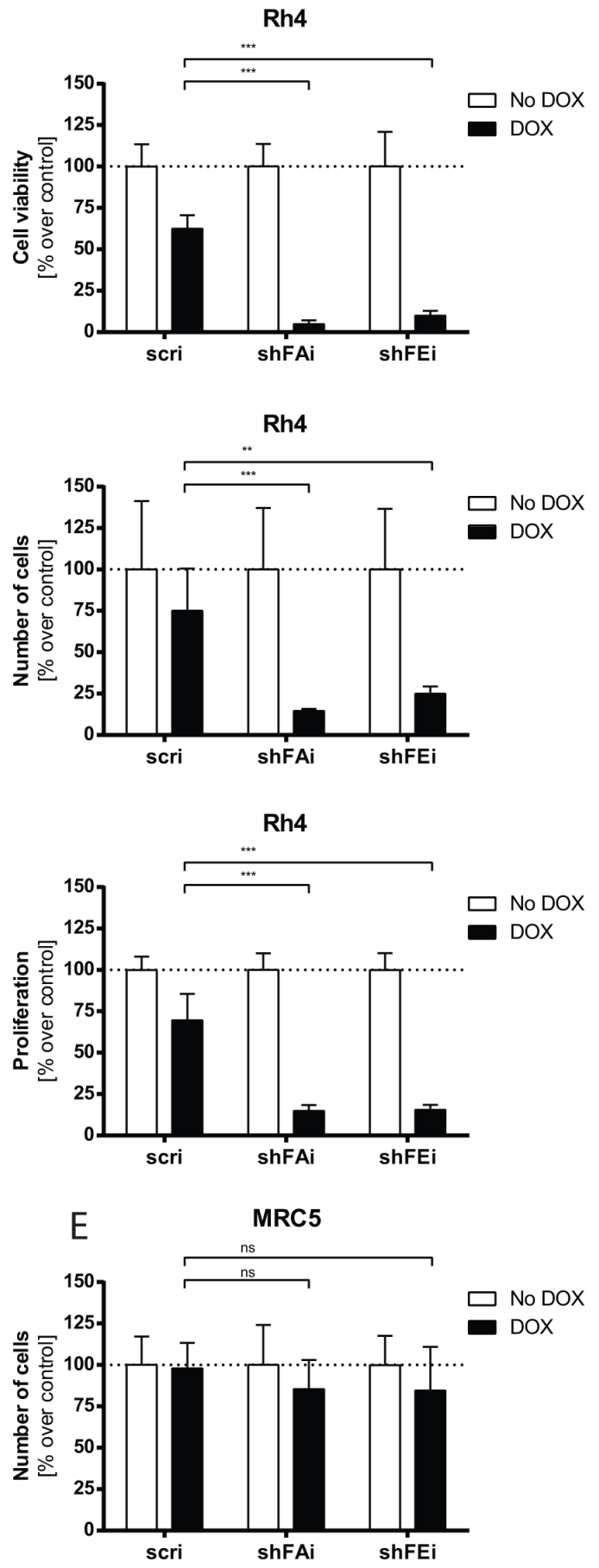

Figure 2: Cell viability and proliferation of aRMS cells are decreased upon furin silencing. Rh30, Rh4 and MRC5 cells were treated with $25 \mathrm{ng} / \mathrm{mL}$ DOX for 96h and analyzed. A. Cell viability in Rh30 and Rh4 cells was determined with a WST-1 assay. B. The number of Rh30 and Rh4 cells was quantified by staining with crystal violet. C. Proliferation in Rh30 and Rh4 cells was measured by incorporation of BrdU. D. Cell viability in MRC5 cells was determined with a WST-1 assay. E. The number of MRC5 cells was quantified by staining with crystal violet. All data represent mean $\pm \mathrm{SD}$ of three independent experiments. ${ }^{*} \mathrm{P}<0.05, * * \mathrm{P}<0.01,{ }^{*} * * \mathrm{P}<0.005$, two-way ANOVA. 


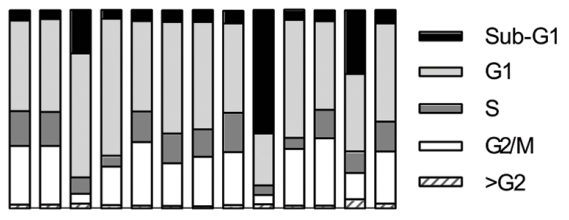

$100 \mathrm{ng} / \mathrm{ml} \mathrm{DOX}-+-$ - $_{+}+++-++$

BEZIAEW - - + + - - - - - - -

$100 \mu \mathrm{M} z V A D$ - $-++\cdots$
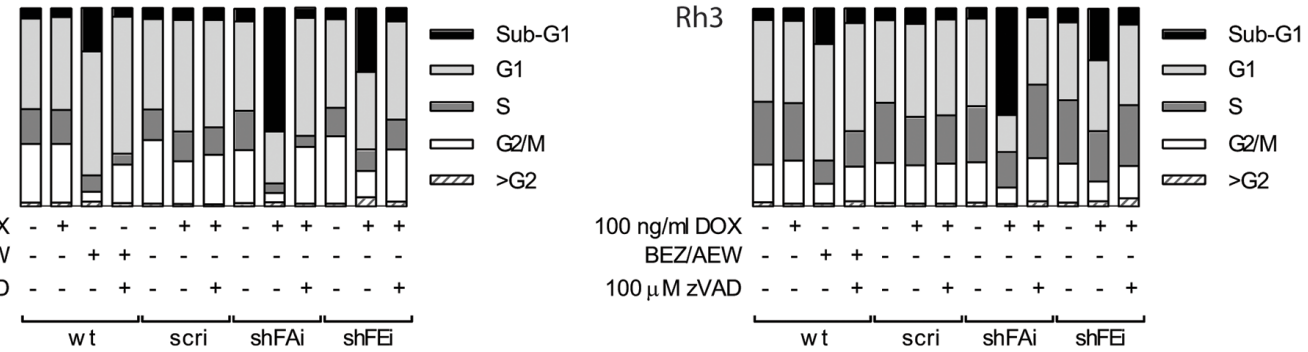

$100 \mathrm{ng} / \mathrm{ml} \mathrm{DOX}-+\ldots++++_{+}++$

BEZIAEW - + + - - - - - - - - -

$100 \mu \mathrm{M} z V A D$ - $-++\ldots$

wt scri shFAi shFE

B

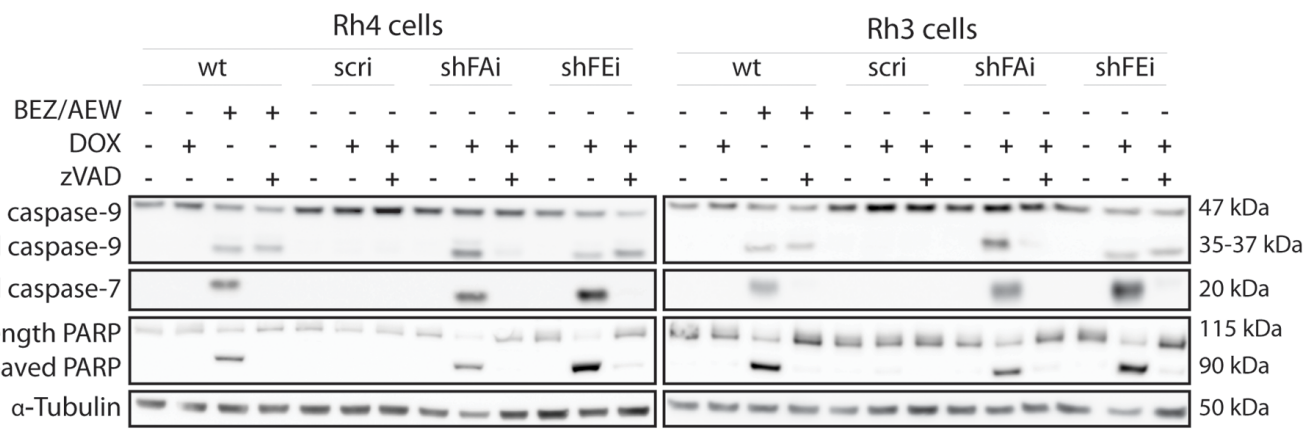

C

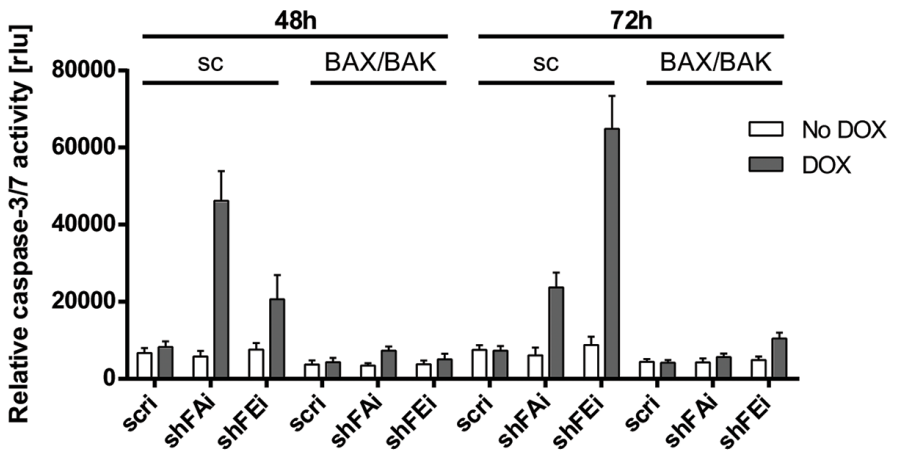

D

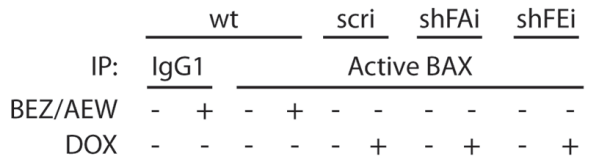

Rh4 cells

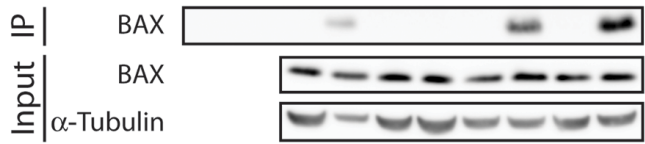

Rh3 cells

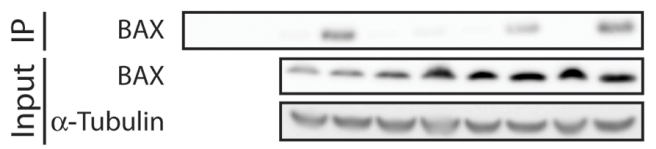

Figure 3: Cell death induction upon furin silencing is caspase dependent and involves mitochondria. A. Caspase inhibition restores normal cell cycle distribution. Rh4 and Rh3 cells were treated with $100 \mathrm{ng} / \mathrm{mL}$ DOX for $72 \mathrm{~h}$ in the presence or absence of $100 \mu \mathrm{M}$ zVAD, fixed and stained with propidium iodide and cell cycle distribution was studied by FACS. B. Inhibition of caspase activity rescues cleavage of caspase-7 and PARP, but not caspase-9 cleavage. Furin silencing was induced in Rh4 (left panel) and Rh3 (right panel) cells by addition of $100 \mathrm{ng} / \mathrm{mL}$ DOX in the presence or absence of zVAD, total protein was extracted $72 \mathrm{~h}$ post induction, and cleavage of caspase-9 and -7 and PARP was analyzed by immunoblotting. Wt cells were treated with $275 \mathrm{nM}$ BEZ235 and $1 \mu \mathrm{M}$ AEW451 for $24 \mathrm{~h}$ as positive control (A-B, D). C. Effector caspase activation is mitochondria dependent. Rh4 cells with a stable BAX and BAK (BAX/BAK) or control (sc) knock out were generated using a lentiviral CRISPR/Cas9 based approach. Knock out cells were stably transduced with inducible furin silencing constructs. Cells were treated with $100 \mathrm{ng} / \mathrm{mL}$ DOX for 48 and $72 \mathrm{~h}$ and caspase- $3 / 7$ activity was analyzed by a caspase specific luminescent assay. Data represent mean $\pm \mathrm{SD}$ of three independent experiments. ${ }^{*} \mathrm{P}<0.05,{ }^{*} * \mathrm{P}<0.01,{ }^{*} * * \mathrm{P}<0.005$, two-way ANOVA. D. Apoptosis induction is dependent on BAX activation. Rh4 and Rh3 cells were treated with $100 \mathrm{ng} / \mathrm{mL}$ DOX for $48 \mathrm{~h}$ (scri, shFAi) or $72 \mathrm{~h}$ (shFEi) and active BAX was immunoprecipitated using a conformation-specific antibody. 
Cleavage of the effector caspase- 7 and of PARP could be almost completely prevented in the presence of zVAD, whereby inhibition of caspase- 9 cleavage was incomplete (Figure 3B). Caspase activity of the caspases-3 and -7 was elevated 5 to 7-fold upon furin silencing in Rh4 and Rh3 (Figure 3C and data not shown), but not in Rh30 or CW9019 cells (data not shown). This suggests that in some aRMS cells furin silencing mainly inhibits proliferation and viability, whereas in other aRMS cell lines a decrease in furin activity additionally induces caspase-dependent cell death. Therefore, application of zVAD to Rh4 cells upon induction of furin silencing only partially rescued cell viability as assessed by measuring cell viability and number of attached cells (Supplementary Figure S3A and $\mathrm{S} 3 \mathrm{~B})$. In this case caspase inhibition prevented apoptosis, but did not decrease anti-proliferative processes.

To examine the involvement of mitochondria in apoptosis induced by furin silencing we generated Rh4 cells with a stable double knock out of BAX and BAK (BAX/ BAK) or control (sc) knock out. Levels of BAX and BAK proteins in heterogeneous cell pools were investigated by immunoblotting. For both proteins knock out efficiency was almost complete (Supplementary Figure S4). Rh4 cells with BAX/BAK or control knock out were then transduced with inducible furin shRNA as described above. In control knock out Rh4 caspase-3/7 activity peaked at $48 \mathrm{~h}$ for shFAi and at $72 \mathrm{~h}$ for shFEi and was elevated 7.9-fold or 7.4-fold when compared to non-treated cells. In contrast, caspase-3/7 activity levels were increased only minimally upon furin silencing in the absence of BAX and BAK (Figure 3C). Furin silencing in Rh4 and Rh3 cells further stimulated activation of BAX, as was shown by immunoprecipitation of BAX with active conformation-specific antibodies (Figure 3D). These results suggest that furin silencing leads to caspase-dependent apoptosis that relies on mitochondria pore formation through $\mathrm{BAX}$ and $\mathrm{BAK}$.

\section{Furin silencing results in remission of $\mathrm{Rh} 4$ xenografts in vivo}

Reduced furin activity decreased cell viability and proliferation in Rh4 cells and further induced caspasedependent apoptosis in vitro. To examine the role of furin in Rh4 tumor growth we engrafted 3.25 million cells harboring either inducible furin shRNA (shFAi and shFEi) or control shRNA (scri). In order to simulate a potential therapy aiming at abrogating furin activity in established tumors, mice were treated with DOX once tumors reached a size of 200-300 $\mathrm{mm}^{3}$ (Figure 4A). Mice were sacrificed upon reaching a tumor size of $1000 \mathrm{~mm}^{3}$. PBS-treated tumors took on average 16-17 days to attain this size (Figure 4Bscri: 17 days; shFAi: 16.6 days; shFEi: 16.5 days). Rh4 scri tumors treated with DOX showed slightly decelerated tumor growth and took on average 25 days to reach a size of 1000 $\mathrm{mm}^{3}$. In contrast, Rh4 shFAi and shFEi tumors went into full remission after 10-15 days. 4 out of 5 Rh4 shFAi tumors relapsed 9-20 days later, whereby the last tumor of this group never relapsed, not even after DOX withdrawal 60 days post remission. None of the Rh4 shFEi DOX-treated mice relapsed (Figure 4B). Assessment of furin mRNA by qRT-PCR revealed that only half of Rh4 shFAi DOX-treated relapsed tumors maintained low levels of furin. The other two tumors showed higher furin mRNA levels $(41 \%$ and $75 \%$ over control treated Rh4 shFAi tumors), indicating a possible outgrowth of cells with ineffective furin silencing (Figure 4C). To further investigate the mechanisms leading to remission of Rh4 shFAi and shFEi tumors upon DOX administration, we sacrificed few mice 5 days after initial administration of DOX. Decreased furin mRNA levels were confirmed by qRT-PCR (Supplementary Figure S5 - shFAi: around 30\%; shFEi: 15\%). Total protein was extracted from tumor tissue and protein levels of different cell death markers were examined by immunoblotting. The three tumors with lower furin levels displayed elevated levels of cleaved caspase- 9 and -7 and cleaved PARP as compared to Rh4 scri tumors (Figure 4D). Furthermore, Rh4 shFEi, but especially shFAi tumors showed high levels of cleaved caspase- 3 after 5 days of DOX treatment (Figure $4 \mathrm{E}$ ). Expression of scri in control tumors did not lead to activation of this effector caspase.

Thus, we could show that induced silencing of furin leads to full remission of Rh4 tumors in vivo. This is most likely achieved through initiation of apoptotic processes, as shown by activation of key caspases. Beside reactivation of furin expression, other, yet undetermined, processes might lead to relapse of tumors and should be further investigated.

\section{Tumor growth of Rh30 xenografts in vivo is delayed after furin silencing}

Induction of furin silencing diminished proliferation and cell viability of Rh30 cells in vitro. To determine the impact of furin activity on Rh30 tumor growth in vivo we engrafted 2.5 million Rh30 cells with inducible furin shRNA and shRNA expression was induced by administration of DOX-supplemented food 7 days prior engraftment of tumor cells (Figure 5A). Control groups were fed normal food. Tumor growth was monitored over time through caliper measurements and mice were sacrificed once tumors reached a size of $1000 \mathrm{~mm}^{3}$. Rh30 scri tumor growth was similar with or without DOX supplement and tumors reached a size of $300 \mathrm{~mm}^{3}$ after 25 days. Conversely, early tumor growth was clearly delayed in Rh30 shFAi and shFEi tumors in the presence of DOX and tumors took approximately 50\% more time to reach 300 $\mathrm{mm}^{3}$ (Figure 5B, shFAi - no DOX: 21 days, DOX: 31 days; shFEi - no DOX: 22 days, DOX: 34 days). After reaching a size of $300 \mathrm{~mm}^{3}$ most Rh30 tumors grew at the same pace independent of the genetic background. To investigate furin silencing efficiency we extracted RNA from tumor tissue at sacrifice and evaluated furin mRNA levels by qRT-PCR. 
Furin mRNA levels of Rh30 shFAi or shFEi tumors with DOX as compared to respective tumors without DOX were on average $15 \%$ and $11 \%$, respectively (Figure 5C), confirming effective furin silencing. Despite having low furin levels, once furin silenced Rh30 tumors exceeded a size of approximately $300 \mathrm{~mm}^{3}$, they grew almost as fast as control tumors. However, a clear delay in early tumor growth could be observed, suggesting that furin activity is important in early phases of Rh30 tumor growth in vivo.

\section{Most RMS biopsies express furin}

To evaluate the potential of furin targeted therapies in patients we examined furin protein expression in 89 RMS biopsies (74 eRMS, 15 aRMS). A TMA was stained for furin and expression was graded according to overall intensity of the staining in tumor cells (Figure $6 \mathrm{~A})$. We found that, independent of the subtype, over $86 \%$ of RMS tumors expressed low to high amounts of

A Rh4 xenografts

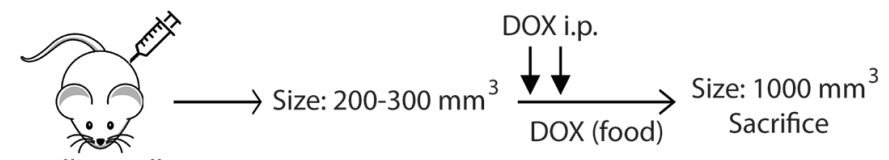

3.25 million cells, s.c.

B

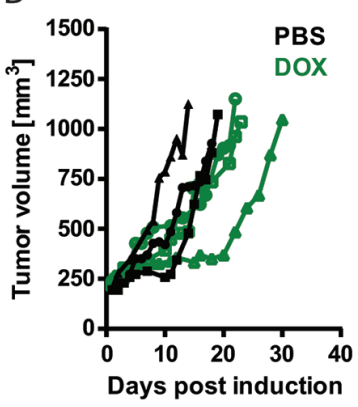

Rh4 shFAi

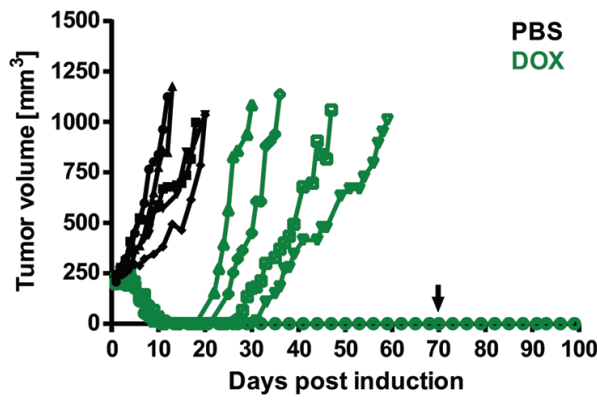

Rh4 shFEi

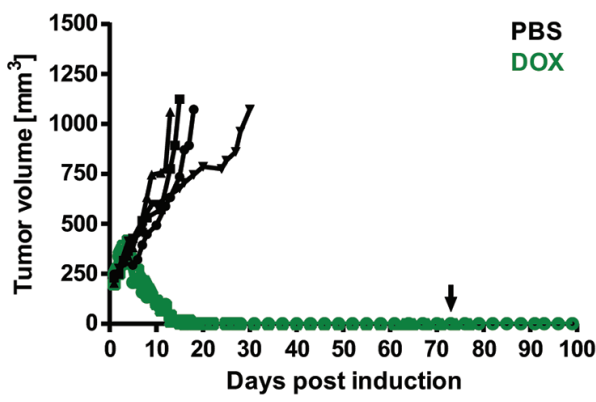

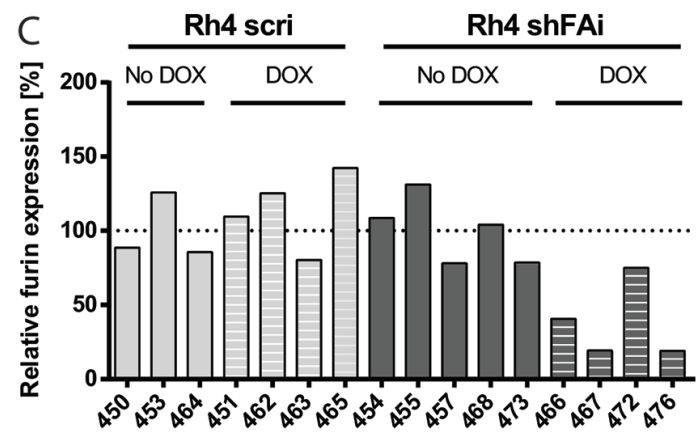

D

$$
\frac{\text { scri }}{480} \frac{\text { shFAi }}{481 \quad 485} \frac{\text { scri }}{447} \frac{\text { shFEi }}{443}
$$

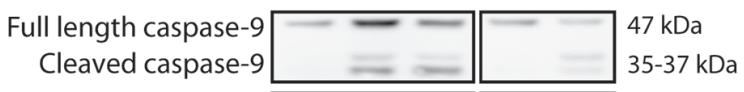

Cleaved caspase-7 $20 \mathrm{kDa}$

Full length PARP $-\square 115 \mathrm{kDa}$

Cleaved PARP _ _ _ $\quad 90 \mathrm{kDa}$

$a$-Tubulin $=50 \mathrm{kDa}$

$E$

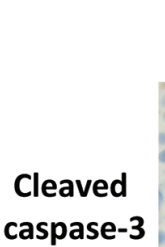

Rh4 scri 480

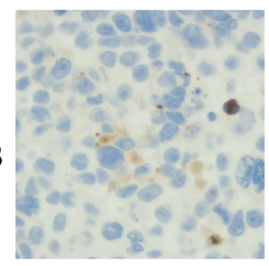

Rh4 ShFAi 481

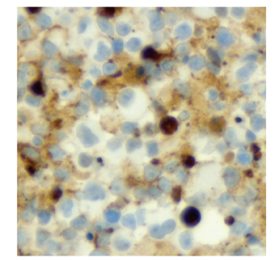

Rh4 ShFAi 485

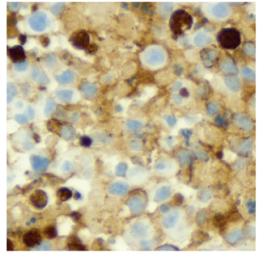

Rh4 scri 447

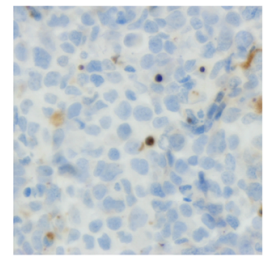

Rh4 shFEi 443

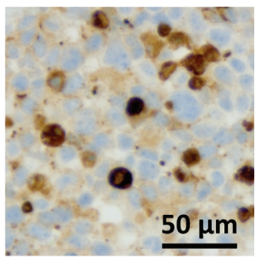

Figure 4: Induction of furin silencing results in remission of Rh4 tumors in vivo. A. Schematic overview of Rh4 xenograft model. 3-5 NOD/SCID mice per group were engrafted s.c. with 3.25 million Rh4 cells. Expression of shRNA was induced through administration of DOX (i.p. injection of $53 \mathrm{mg} / \mathrm{kg}$ DOX on two consecutive days combined with DOX-supplemented food) once a tumor size of 200-300 $\mathrm{mm}^{3}$ was reached. Mice were sacrificed upon a tumor size of $1000 \mathrm{~mm}^{3}$. B. Tumor growth over time as monitored by caliper measurements in Rh4 xenografts. Arrows indicate that mice were put back on normal food approximately 60 days post onset of remission. C. Furin mRNA levels in Rh4 tumors. Tumor tissue was collected at sacrifice, total RNA isolated and furin mRNA levels analyzed by qRT-PCR. D-E. Apoptotic markers in Rh4 tumors after 5 days of DOX treatment. D) Caspase-9, cleaved caspase-7 and PARP levels were examined by Western blot. E) Levels of cleaved caspase-3 were analyzed by immunohistochemistry. 
furin (Figure 6B), whereby most tumors showed low to intermediate expression. A correlation between the level of furin protein in tumors and event-free or overall survival of the patients could not be confirmed (data not shown).

\section{DISCUSSION}

This study establishes for the first time a link between furin activity and rhabdomyosarcoma progression both in vitro and in vivo. Silencing of furin led to significantly decreased cell viability and induction of caspase-dependent apoptosis in vitro. Furthermore, depletion of furin activity in vivo resulted in regression or delayed tumor growth of aRMS tumors.

Furin is known to process many growth factors and their receptors, like IGF-1 and 2, IGF1R or transforming growth factor $\beta$ (TGF $\beta$ ) $[34,35]$. Accordingly, silencing of furin led to significant reduction of cell viability and proliferation rate in all investigated aRMS cell lines. Furin silencing had no effect on MRC5 fibroblast viability, suggesting that aRMS, but not normal cells are dependent on furin activity. A subset of the aRMS cell lines tested was particularly sensitive to furin silencing and underwent BAX/BAK- and caspase-9-dependent apoptosis. This indicates that furin silencing primarily triggers the intrinsic apoptotic pathway. Others have shown that disruption of the IGF1R and/or PI3K/mTOR pathways leads to apoptosis in Rh3 and Rh4 cell lines [12, 33]. In this study we found evidence that activation of the IGF signaling pathway is dependent on furin activity. We therefore hypothesize that incomplete activation of growth factor-dependent pathways is the principal cause of cell death induced upon furin silencing in sensitive cell lines. It remains to be investigated which proapototic $\mathrm{BH} 3$-only proteins are involved, but treatment of Rh3 and Rh4 cells with a combination of the IGF1R inhibitor AEW541 and the dual PI3K/mTOR inhibitor BEZ235 results in BMFdependent apoptosis [33]. Other proapototic BH3-only proteins linked to growth factor deprivation are BAD, BIM and PUMA. For instance, phosphorylation of BAD through active protein kinase Akt results in binding and sequestration by 14-3-3 scaffold proteins [36, 37]. Thus, lower levels of activated Akt due to decreased IGF signaling upon furin silencing might promote release of BAD and mitochondria pore formation. Further investigations will be required to elucidate the exact mechanism of cell death after silencing of furin.

To examine the impact of furin silencing on aRMS tumor growth in vivo we engrafted two aRMS cell lines, Rh30 and the sensitive Rh4. In Rh30 xenografts, upon furin silencing, we observed delay of early tumor growth, suggesting that furin cleaves one or more precursor proteins that are crucial for early steps of aRMS tumor growth after xenotransplantation.

A signaling pathway likely to be involved is the VEGF signaling axis. Gee et al. confirmed expression of VEGF, VEGFR1, which is a transcriptional target of PAX3-FOXO1 [38], and VEGFR2 in aRMS cell lines and were the first to propose a role of VEGF signaling in RMS growth [39]. Processing of precursor VEGF-C and VEGF-D through furin allows their binding to VEGFR2 and induction of vasculogenesis and angiogenesis [19, 40 42]. Additionally, only furin-processed VEGF-C induces tumorigenesis in mice [19], highlighting the importance

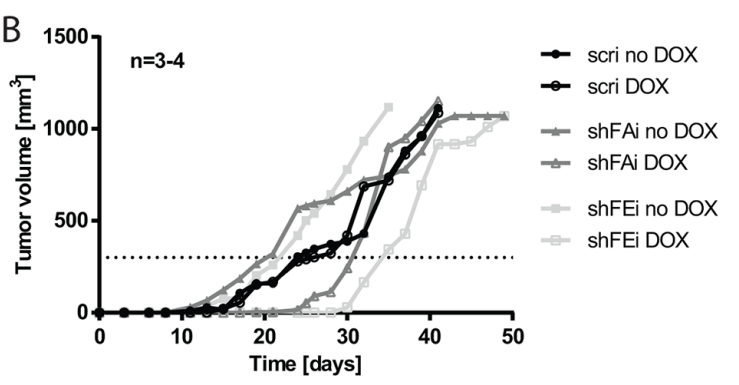

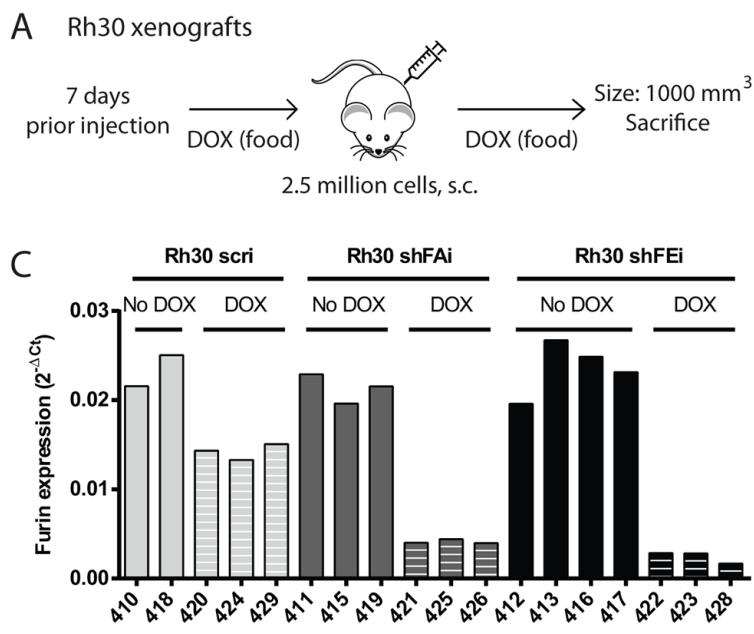

Figure 5: Decrease of furin activity delays tumor growth of Rh30 xenografts in vivo. A. Schematic overview of Rh30 xenograft model. 3-4 NOD/Scid mice per group were fed with or without DOX-supplemented food starting 7 days prior engraftment. Mice were then engrafted s.c. with 2.5 million Rh30 cells. Tumor growth was monitored over time and mice were sacrificed once a tumor reached a size of $1000 \mathrm{~mm}^{3}$. B. Absence of furin activity delays initial tumor growth. Tumor growth rate was monitored by caliper measurements. Data represent mean tumor size of 3-4 mice per group. C. Furin expression is reduced upon induction of furin specific shRNA. Tumor tissue was collected upon sacrifice of mice, total RNA isolated and furin mRNA levels analyzed by qRT-PCR. Expression levels relative to HMBS are shown. 
of PC activity in the VEGF signaling axis. Therefore, reduced VEGF-C and VEGF-D processing upon furin silencing might suppress proper formation of angiogenic and lymphangiogenic vessels inside the new tumors and decrease VEGFR2-dependent aRMS tumor cell growth.

When furin was silenced in established Rh4 tumors, regression was observed. Apoptosis was induced, as confirmed by activation of caspases-9, -3 and -7 and PARP cleavage. Four of the Rh4 shFAi tumors relapsed and furin re-expression was found in two of them. Since we used a heterogeneous cell pool, it is likely that outgrowth of a subset of non-silenced cells caused the relapse. Further investigations will be required to uncover the underlying mechanisms of tumor regrowth.
We found furin expression in over $86 \%$ of tested aRMS and eRMS biopsies, but no significant correlation could be confirmed between furin expression and eventfree or overall survival. It is possible that other riskfactors interacted with the analysis of furin influence on survival, or that furin expression alone is not a good marker for its role in cancerogenesis, but rather its subcellular localization and activity are. Our results are in line with other studies demonstrating the role of furin and other PCs for cancer cell survival [15, 28, 43]. Thus, PCs are emerging targets for the treatment of cancer and development of specific inhibitors will be of central importance. Levesque et al. recently reported the improvement of peptide-based specific PACE4
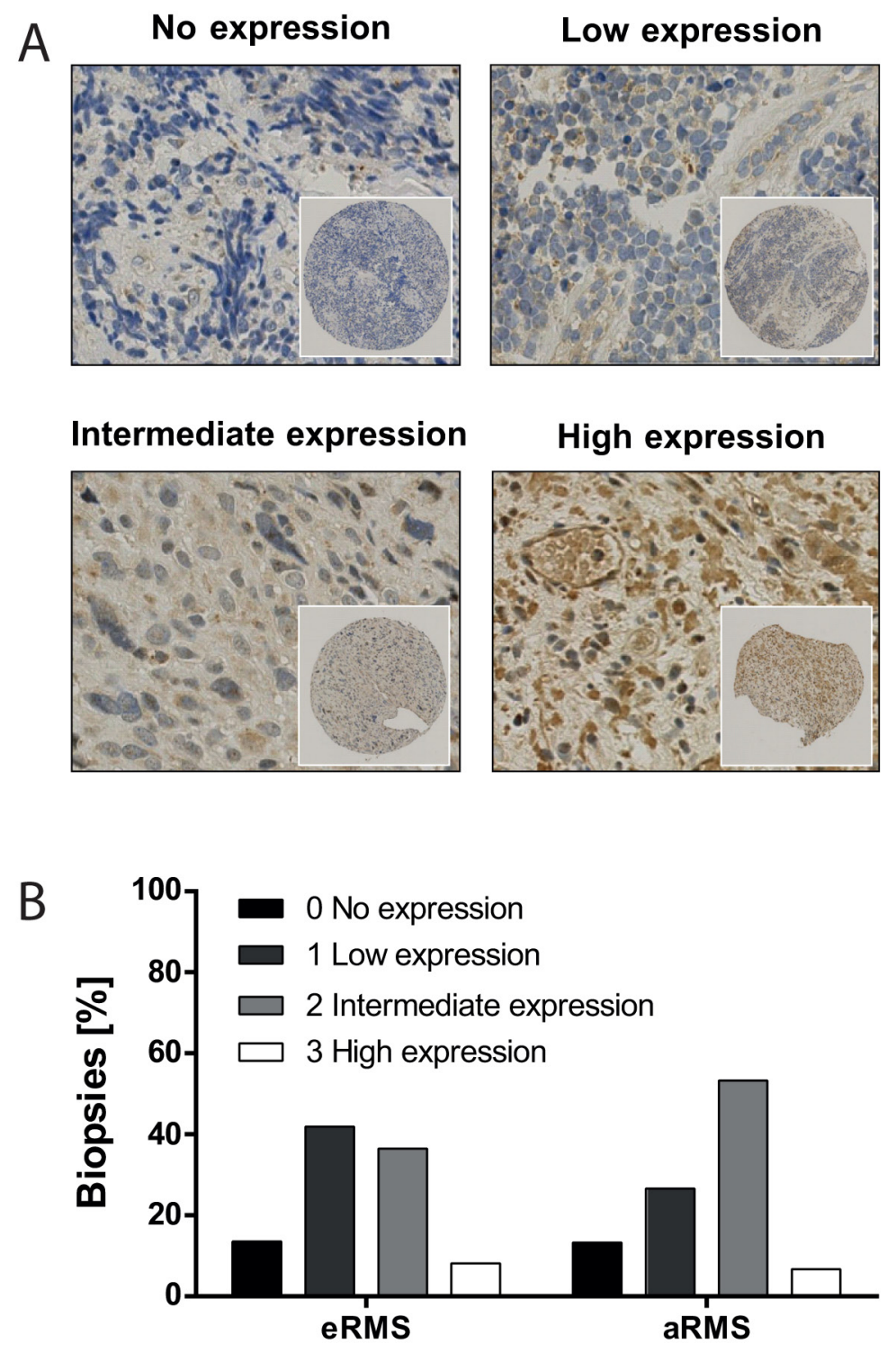

Figure 6: Furin is expressed in most RMS biopsies. A patient-derived tissue microarray was immunohistochemically stained for furin $(n=89)$. Patients were grouped according to no expression $(n=12)$, low $(n=35)$, intermediate $(n=35)$ and high $(n=7)$ furin expression. A. Representative pictures of biopsies from all four categories. B. Distribution of furin expression intensity based on RMS subtype. Furin expression levels were analyzed for 74 eRMS and 15 aRMS biopsies. 
inhibitors for treatment of prostate cancer [44, 45] and Zhu et al. described the first furin-specific inhibitory nanobodies [30]. Despite their great clinical potential, specific inhibitors of furin and furin-like PCs are still in early phases of development. Besides, the safety of such inhibitors will have to be closely examined as most PCs are widely expressed in human tissues. Nevertheless, disruption of furin activity has been used successfully to enhance an anti-tumor immune response in patients with advanced cancers. Safety and efficient immune response of an autologous tumor cell vaccine (FANG) that combines furin shRNA and expression of GM-CSF were confirmed and benefits of treatment were observed from phase I trials in Ewing sarcoma and hepatocellular carcinoma patients [46-48]. Additionally, increased presence of furin on the cell surface of tumor cells could be used for targeted delivery of chemotherapeutics, as we could show previously that furin is the target receptor for RMS-homing peptides [32]. In conclusion, our data clearly validate furin as a novel target in aRMS and we predict that the majority of pediatric RMS patients would benefit from inhibition of furin activity, either alone or in the context of immune therapy.

\section{MATERIALS AND METHODS}

\section{Cell lines and cell culture}

The cell lines Rh4, Rh30 (Peter Houghton, St. Jude Children's Hospital, Memphis, TN), Rh3 (Susan Ragsdale, St. Jude Children's Hospital, Memphis, TN), CW9019 (Soledad Gallego, Hospital Universitari Vall d'Hebron, Barcelona, Spain), MRC5 and HEK293T (ATCC, LGC Promochem) were cultured in DMEM (Sigma-Aldrich), supplemented with $100 \mathrm{U} / \mathrm{mL}$ penicillin/streptomycin, $2 \mathrm{mM}$ L-glutamine, and 10\% FBS (Life Technologies) in $5 \% \mathrm{CO}_{2}$ at $37{ }^{\circ} \mathrm{C}$. aRMS cell lines were tested and authenticated by cell line typing analysis (STR profiling) on 2011/2014 and positively matched [49].

\section{Production of lentiviral particles and transduction of cells}

Production of lentiviral particles and transduction of cells are described in Supplementary Material and Methods.

\section{qRT-PCR}

Total RNA was extracted from cells or tumor tissue using the Qiagen RNeasy Kit (Qiagen, Hombrechtikon, Switzerland) and reverse-transcribed using oligo (dT) primers and Omniscript reverse transcriptase (Qiagen). qRT-PCR pas performed for furin (Hs00965485_g1), PC1 (Hs01026107_m1), PC2 (Hs0015992_m1), PC4 (Hs00399493_m1), PC5 (Hs00196400_m1), PACE4
(Hs00159844_m1), PC7 (Hs00237114_m1), S1P (Hs00921626_m1) and PCSK9 (Hs00545399_m1) employing TaqMan gene expression master mix (all Life Technologies). Cycle threshold $\left(\mathrm{C}_{\mathrm{T}}\right)$ values were normalized to GAPDH (Hs02758991_g1) or HMBS (Hs00609296_g1) for cells or tumor tissue, respectively. Relative expression levels were calculated using the $\Delta \Delta \mathrm{C}_{\mathrm{T}}$ method.

\section{Immunoblotting}

Total protein extracts from cells or tumor tissue were separated using 4-12\% Bis-Tris SDS-PAGE gels (Life Technologies) and transferred to nitrocellulose membranes (PROTAN; Schleicher \& Schuell). Membranes were blocked with $5 \%$ milk powder in TBS $/ 0.05 \%$ Tween and subsequently incubated with primary antibodies overnight at $4^{\circ} \mathrm{C}$. After washing in TBS, membranes were incubated with IgG horseradish peroxidase (HRP)-linked antibody for $1 \mathrm{~h}$ at RT. Proteins were detected using ECL detection reagent (Fisher Scientific) after washing in TBS.

\section{IGF1 stimulation}

RMS cells were treated with $25 \mathrm{ng} / \mathrm{mL}$ DOX for a total of $48 \mathrm{~h}$. After $24 \mathrm{~h}$ cells were put on starvation medium (DMEM, 0.2\% FBS). Cells were stimulated for $10 \mathrm{~min}$ with $50 \mathrm{ng} / \mathrm{mL}$ IGF1 (ab73455, Abcam). Cells were washed with ice-cold PBS and snap frozen in liquid nitrogen. Whole cell lysates were prepared as described above and IGF1R $\beta$, Akt, phosphorylated Akt, Erk1/2 and phosphorylated Erk1/2 were analyzed by immunoblotting.

\section{Antibodies}

Antibodies are described in Supplementary Material and Methods.

\section{Cell proliferation and viability assays}

Cells were seeded in a 96-well format in $100 \mu \mathrm{L}$ medium. To assess cell viability $10 \mu \mathrm{L}$ WST-1 reagent (Roche) were added. After $30-60 \mathrm{~min}$ incubation at $37^{\circ} \mathrm{C}$ in the dark absorbance was measured and recorded as $\triangle \mathrm{OD}_{440-}$ ${ }_{640}$. Background values were subtracted. To determine their number, cells were fixed in 4\% paraformaldehyde for 10 min at RT and stained in $0.05 \%$ crystal violet (SigmaAldrich) for $20 \mathrm{~min}$ at RT. Excess crystal violet was removed and cells air dried. Dye was dissolved in 100\% methanol and absorbance was measured at $\mathrm{OD}_{594}$. Cell proliferation was determined through BrdU incorporation (Cell Proliferation ELISA, BrdU (Chemiluminescent), Roche) according to manufacturer's instructions. Cells were labeled with $\mathrm{BrdU}$ for $2 \mathrm{~h}$ at $37^{\circ} \mathrm{C}$, fixed and stained for $1 \mathrm{~h}$ with anti-BrdU-POD solution. Chemiluminescent substrate was added and luminescence measured. 


\section{Caspase 3/7 activity}

Cells were seeded in a 384-well format in $20 \mu \mathrm{L}$ medium. At the desired time point $10 \mu \mathrm{L}$ Caspase $\mathrm{Glo}^{\circledR}$ 3/7 Substrate (Promega) were added and plates vigorously shaken for $1 \mathrm{~min}$. After $30 \mathrm{~min}$ incubation at RT in the dark luminescence was measured.

\section{Cell cycle distribution}

One million cells were collected and fixed in ice cold $70 \%$ ethanol at $-20^{\circ} \mathrm{C}$ for at least $2 \mathrm{~h}$. Fixed cells were washed in PBS and resuspended in propidium iodide (PI) solution $(20 \mu \mathrm{g} / \mathrm{mL}$ PI and $200 \mu \mathrm{g} / \mathrm{mL}$ RNase A (SigmaAldrich) in PBS $/ 0.1 \%$ Triton X-100). PI signal was assessed by FACS. Cell cycle distribution was analyzed with FlowJo software, version 10 (TreeStar).

\section{Immunoprecipitation of active $\mathrm{BAX}$}

For detection of active BAX, cells were lysed in CHAPS lysis buffer (10 mM HEPES (pH 7.4), $150 \mathrm{mM}$ $\mathrm{NaCl}, 1 \%$ CHAPS) as previously described [50]. Briefly, $1000 \mu \mathrm{g}$ protein were incubated overnight at $4^{\circ} \mathrm{C}$ with $5 \mu \mathrm{g}$ mouse anti-BAX antibody (6A7, Sigma) followed by addition of $10 \mu \mathrm{L}$ Dynabeads Protein G (Invitrogen) and further incubation for $2 \mathrm{~h}$ at $4^{\circ} \mathrm{C}$. Dynabeads were washed with lysis buffer and BAX levels were analyzed by immunoblotting using rabbit anti-BAX $(1: 1000 ; 5023$, Cell Signaling).

\section{Xenograft studies}

To study in vivo growth $2.5 \times 10^{6} \mathrm{Rh} 30$ or $3.25 \times 10^{6}$ $\mathrm{Rh} 4$ cells were engrafted subcutaneously in 6-weekold NOD/SCID IL2 $\mathrm{rg}^{-/}$mice (female, 20-25 g; Charles River). In Rh30 xenografts doxycycline (DOX)supplemented food $(625 \mathrm{mg} / \mathrm{kg}$, Synergy Health, Däniken, Switzerland) was given one week prior engraftment. DOX administration in Rh4 xenografts was started upon a tumor size of 200-300 $\mathrm{mm}^{3}$ through intraperitoneal (i.p.) injection of $0.053 \mathrm{mg} \mathrm{DOX} / \mathrm{g}$ body weight on two consecutive days and continuous DOX-supplemented food. Control treated mice were injected with PBS. Body weight and tumor growth were monitored over time. Tumor volumes were determined by measuring two diameters $(\mathrm{d} 1, \mathrm{~d} 2)$ in right angles using a digital caliper $\left(\mathrm{V}=(4 / 3) \pi \mathrm{r}^{3} ; \mathrm{r}=\right.$ $(\mathrm{d} 1+\mathrm{d} 2) / 4)$. Upon reaching a tumor size of $1000 \mathrm{~mm}^{3}$ mice were sacrificed, tumor tissue was harvested and snap frozen for RNA and protein extraction.

\section{Immunohistochemistry}

Sections (3- $\mu \mathrm{m}$ thick) of formalin-fixed, paraffinembedded tissue were mounted on glass slides (SuperFrost Plus; Menzel), deparaffinised, rehydrated and stained with hematoxylin and eosin (H\&E). Immunohistochemistry was performed on Leica BondMax instruments using Refine HRP-Kits (Leica DS9800; Leica Microsystems Newcastle, Ltd.). Dewaxed and pretreated (Epitop Retrieval Buffer 2, Leica Biosystems, Muttenz, Switzerland; $60 \mathrm{~min}, 100^{\circ} \mathrm{C}$ ) paraffin slides were incubated with anti-cleaved caspase-3 antibody (1:500; \#9661, Cell Signaling).

\section{Tissue microarray}

A tissue microarray with 248 cores from 124 RMS tumors (17 aRMS with known FOXO1 gene rearrangements and 107 eRMS) was constructed. Tumors used were collected at the University Hospital Zurich, Switzerland and at the Kiel Pediatric Tumor Registry, Germany. Immunohistochemistry was performed essentially as described above. Paraffin slides were dewaxed, pretreated (Epitop Retrieval Buffer 2, Leica Biosystems;10 min, $\left.95^{\circ} \mathrm{C}\right)$ and incubated with furin antibody $(1: 3000 ; \mathrm{Ab} 28547$, Abcam). Overall staining was graded according to intensity and assigned to four different groups (no expression, low, intermediate or high expression). Tissue microarrays were analyzed double-blinded.

\section{CONFLICTS OF INTEREST}

No potential conflicts of interest.

\section{GRANT SUPPORT}

This study was supported by Swiss Research Foundation Child and Cancer, Cancer League of the Kanton Zurich, and Forschungskredit University of Zurich.

\section{REFERENCES}

1. Ognjanovic S, Linabery AM, Charbonneau B and Ross JA. Trends in childhood rhabdomyosarcoma incidence and survival in the United States, 1975-2005. Cancer. 2009; 115:4218-4226.

2. Davicioni E, Finckenstein FG, Shahbazian V, Buckley JD, Triche TJ and Anderson MJ. Identification of a PAX-FKHR gene expression signature that defines molecular classes and determines the prognosis of alveolar rhabdomyosarcomas. Cancer Res. 2006; 66:6936-6946.

3. Wachtel M, Dettling M, Koscielniak E, Stegmaier S, Treuner J, Simon-Klingenstein K, Buhlmann P, Niggli FK and Schafer BW. Gene expression signatures identify rhabdomyosarcoma subtypes and detect a novel $\mathrm{t}(2 ; 2)$ (q35;p23) translocation fusing PAX3 to NCOA1. Cancer Res. 2004; 64:5539-5545.

4. Shern JF, Chen L, Chmielecki J, Wei JS, Patidar R, Rosenberg M, Ambrogio L, Auclair D, Wang J, Song YK, Tolman C, Hurd L, Liao H, et al. Comprehensive genomic analysis of rhabdomyosarcoma reveals a landscape of 
alterations affecting a common genetic axis in fusionpositive and fusion-negative tumors. Cancer Discov. 2014; 4:216-231.

5. Sorensen PH, Lynch JC, Qualman SJ, Tirabosco R, Lim JF, Maurer HM, Bridge JA, Crist WM, Triche TJ and Barr FG. PAX3-FKHR and PAX7-FKHR gene fusions are prognostic indicators in alveolar rhabdomyosarcoma: a report from the children's oncology group. J Clin Oncol. 2002; 20:2672-2679.

6. Ayalon D, Glaser $\mathrm{T}$ and Werner H. Transcriptional regulation of IGF-I receptor gene expression by the PAX3FKHR oncoprotein. Growth Horm \& IGF Res. 2001; 11:289-297.

7. Blandford MC, Barr FG, Lynch JC, Randall RL, Qualman SJ and Keller C. Rhabdomyosarcomas utilize developmental, myogenic growth factors for disease advantage: a report from the Children's Oncology Group. Pediatr Blood Cancer. 2006; 46:329-338.

8. Gray A, Tam AW, Dull TJ, Hayflick J, Pintar J, Cavenee WK, Koufos A and Ullrich A. Tissue-specific and developmentally regulated transcription of the insulin-like growth factor 2 gene. DNA. 1987; 6:283-295.

9. El-Badry OM, Minniti C, Kohn EC, Houghton PJ, Daughaday WH and Helman LJ. Insulin-like growth factor II acts as an autocrine growth and motility factor in human rhabdomyosarcoma tumors. Cell Growth Differ. 1990; 1:325-331.

10. Shapiro DN, Jones BG, Shapiro LH, Dias P and Houghton PJ. Antisense-mediated reduction in insulin-like growth factor-I receptor expression suppresses the malignant phenotype of a human alveolar rhabdomyosarcoma. J Clin Invest. 1994; 94:1235-1242.

11. Kalebic T, Tsokos M and Helman LJ. In vivo treatment with antibody against IGF-1 receptor suppresses growth of human rhabdomyosarcoma and down-regulates p34cde2. Cancer Res. 1994; 54:5531-5534.

12. Scotlandi K, Manara MC, Nicoletti G, Lollini PL, Lukas S, Benini S, Croci S, Perdichizzi S, Zambelli D, Serra M, Garcia-Echeverria C, Hofmann F and Picci P. Antitumor activity of the insulin-like growth factor-I receptor kinase inhibitor NVP-AEW541 in musculoskeletal tumors. Cancer Res. 2005; 65:3868-3876.

13. Seidah NG and Prat A. The biology and therapeutic targeting of the proprotein convertases. Nat Rev Drug Discov. 2012; 11:367-383.

14. Bennett BD, Denis P, Haniu M, Teplow DB, Kahn S, Louis JC, Citron M and Vassar R. A furin-like convertase mediates propeptide cleavage of BACE, the Alzheimer's beta -secretase. J Biol Chem. 2000; 275:37712-37717.

15. D'Anjou F, Routhier S, Perreault JP, Latil A, Bonnel D, Fournier I, Salzet M and Day R. Molecular Validation of PACE4 as a Target in Prostate Cancer. Transl Oncol. 2011; 4:157-172.

16. Khatib AM, Siegfried G, Prat A, Luis J, Chretien M, Metrakos $\mathrm{P}$ and Seidah NG. Inhibition of proprotein convertases is associated with loss of growth and tumorigenicity of HT-29 human colon carcinoma cells: importance of insulin-like growth factor-1 (IGF-1) receptor processing in IGF-1-mediated functions. J Biol Chem. 2001; 276:30686-30693.

17. Creemers JW, Roebroek AJ and Van de Ven WJ. Expression in human lung tumor cells of the proprotein processing enzyme PC1/PC3. Cloning and primary sequence of a $5 \mathrm{~kb}$ cDNA. FEBS Lett. 1992; 300:82-88.

18. Molloy SS, Thomas L, VanSlyke JK, Stenberg PE and Thomas G. Intracellular trafficking and activation of the furin proprotein convertase: localization to the TGN and recycling from the cell surface. EMBO J. 1994; 13:18-33.

19. Siegfried G, Basak A, Cromlish JA, Benjannet S, Marcinkiewicz J, Chretien M, Seidah NG and Khatib AM. The secretory proprotein convertases furin, PC5, and PC7 activate VEGF-C to induce tumorigenesis. J Clin Invest. 2003; 111:1723-1732.

20. Remacle AG, Rozanov DV, Fugere M, Day R and Strongin AY. Furin regulates the intracellular activation and the uptake rate of cell surface-associated MT1-MMP. Oncogene. 2006; 25:5648-5655.

21. Bassi DE, Mahloogi H, Al-Saleem L, Lopez De Cicco R, Ridge JA and Klein-Szanto AJ. Elevated furin expression in aggressive human head and neck tumors and tumor cell lines. Mol Carcinog. 2001; 31:224-232.

22. Cheng M, Watson PH, Paterson JA, Seidah N, Chretien $\mathrm{M}$ and Shiu RP. Pro-protein convertase gene expression in human breast cancer. Int J Cancer. 1997; 71:966-971.

23. Schalken JA, Roebroek AJ, Oomen PP, Wagenaar SS, Debruyne FM, Bloemers HP and Van de Ven WJ. fur gene expression as a discriminating marker for small cell and nonsmall cell lung carcinomas. J Clin Invest. 1987; 80:1545-1549.

24. Scamuffa N, Siegfried G, Bontemps Y, Ma L, Basak A, Cherel G, Calvo F, Seidah NG and Khatib AM. Selective inhibition of proprotein convertases represses the metastatic potential of human colorectal tumor cells. J Clin Invest. 2008; 118:352-363.

25. McMahon S, Grondin F, McDonald PP, Richard DE and Dubois CM. Hypoxia-enhanced expression of the proprotein convertase furin is mediated by hypoxia-inducible factor-1: impact on the bioactivation of proproteins. J Biol Chem. 2005; 280:6561-6569.

26. Arsenault D, Lucien F and Dubois CM. Hypoxia enhances cancer cell invasion through relocalization of the proprotein convertase furin from the trans-Golgi network to the cell surface. J Cell Physiol. 2012; 227:789-800.

27. Basak A, Chen A, Scamuffa N, Mohottalage D, Basak S and Khatib AM. Blockade of furin activity and furin-induced tumor cells malignant phenotypes by the chemically synthesized human furin prodomain. Curr Med Chem. 2010; 17:2214-2221.

28. Scamuffa N, Sfaxi F, Ma J, Lalou C, Seidah N, Calvo F and Khatib AM. Prodomain of the proprotein convertase subtilisin/ kexin Furin (ppFurin) protects from tumor progression and metastasis. Carcinogenesis. 2014; 35:528-536. 
29. Kacprzak MM, Peinado JR, Than ME, Appel J, Henrich S, Lipkind G, Houghten RA, Bode W and Lindberg I. Inhibition of furin by polyarginine-containing peptides: nanomolar inhibition by nona-D-arginine. J Biol Chem. 2004; 279:36788-36794.

30. Zhu J, Declercq J, Roucourt B, Ghassabeh GH, Meulemans S, Kinne J, David G, Vermorken AJ, Van de Ven WJ, Lindberg I, Muyldermans S and Creemers JW. Generation and characterization of non-competitive furin-inhibiting nanobodies. The Biochemical journal. 2012; 448:73-82.

31. Anderson ED, Thomas L, Hayflick JS and Thomas G. Inhibition of HIV-1 gp160-dependent membrane fusion by a furin-directed alpha 1-antitrypsin variant. J Biol Chem. $1993 ; 268: 24887-24891$.

32. Hajdin K, D'Alessandro V, Niggli FK, Schafer BW and Bernasconi M. Furin targeted drug delivery for treatment of rhabdomyosarcoma in a mouse model. PLoS One. 2010; 5:e10445.

33. Wachtel M, Rakic J, Okoniewski M, Bode P, Niggli F and Schafer BW. FGFR4 signaling couples to Bim and not Bmf to discriminate subsets of alveolar rhabdomyosarcoma cells. Int J Cancer. 2014; 135:1543-1552.

34. Tian S, Huang QS, Fang Y and Wu JH. FurinDB: A Database of 20-Residue Furin Cleavage Site Motifs, Substrates and Their Associated Drugs. Int J Mol Sci. 2011; 12:1060-1065.

35. Lehmann M, André F, Bellan C, Remacle-Bonnet M, Garrouste F, Parat F, Lissitsky JC, Marvaldi J and Pommier G. Deficient processing and activity of type I insulin-like growth factor receptor in the furin-deficient LoVo-C5 cells. Endocrinology. 1998; 139:3763-3771.

36. del Peso L, Gonzalez-Garcia M, Page C, Herrera R and Nunez G. Interleukin-3-induced phosphorylation of BAD through the protein kinase Akt. Science. 1997; 278:687-689.

37. Zha J, Harada H, Yang E, Jockel J and Korsmeyer SJ. Serine phosphorylation of death agonist BAD in response to survival factor results in binding to 14-3-3 not BCL-X(L). Cell. 1996; 87:619-628.

38. Barber TD, Barber MC, Tomescu O, Barr FG, Ruben S and Friedman TB. Identification of target genes regulated by PAX3 and PAX3-FKHR in embryogenesis and alveolar rhabdomyosarcoma. Genomics. 2002; 79:278-284.

39. Gee MF, Tsuchida R, Eichler-Jonsson C, Das B, Baruchel S and Malkin D. Vascular endothelial growth factor acts in an autocrine manner in rhabdomyosarcoma cell lines and can be inhibited with all-trans-retinoic acid. Oncogene. 2005; 24:8025-8037.

40. Joukov V, Sorsa T, Kumar V, Jeltsch M, Claesson-Welsh L, Cao Y, Saksela O, Kalkkinen N and Alitalo K. Proteolytic processing regulates receptor specificity and activity of VEGF-C. EMBO J. 1997; 16:3898-3911.

41. Millauer B, Wizigmann-Voos S, Schnurch H, Martinez R, Moller NP, Risau W and Ullrich A. High affinity VEGF binding and developmental expression suggest Flk-1 as a major regulator of vasculogenesis and angiogenesis. Cell. 1993; 72:835-846.

42. McColl BK, Paavonen K, Karnezis T, Harris NC, Davydova N, Rothacker J, Nice EC, Harder KW, Roufail S, Hibbs ML, Rogers PA, Alitalo K, Stacker SA, et al. Proprotein convertases promote processing of VEGF-D, a critical step for binding the angiogenic receptor VEGFR-2. FASEB J. 2007; 21:1088-1098.

43. Sfaxi F, Scamuffa N, Lalou C, Ma J, Metrakos P, Siegfried G, Ragg H, Bikfalvi A, Calvo F and Khatib AM. Repression of liver colorectal metastasis by the serpin Spn4A a naturally occurring inhibitor of the constitutive secretory proprotein convertases. Oncotarget. 2014; 5:4195-4210. doi: 10.18632/oncotarget.1966.

44. Levesque C, Fugere M, Kwiatkowska A, Couture F, Desjardins R, Routhier S, Moussette P, Prahl A, Lammek B, Appel JR, Houghten RA, D'Anjou F, Dory YL, et al. The Multi-Leu peptide inhibitor discriminates between PACE4 and furin and exhibits antiproliferative effects on prostate cancer cells. J Med Chem. 2012; 55:10501-10511.

45. Levesque C, Couture F, Kwiatkowska A, Desjardins R, Guérin B, Neugebauer WA and Day R. PACE4 inhibitors and their peptidomimetic analogs block prostate cancer tumor progression through quiescence induction increased apoptosis and impaired neovascularisation. Oncotarget. 2015; 6:3680-3693. doi: 10.18632/oncotarget.2918.

46. Senzer N, Barve M, Kuhn J, Melnyk A, Beitsch P, Lazar M, Lifshitz S, Magee M, Oh J, Mill SW, Bedell C, Higgs C, Kumar P, et al. Phase I Trial of "bi-shRNAi(furin)/ GMCSF DNA/Autologous Tumor Cell” Vaccine (FANG) in Advanced Cancer. Mol Ther. 2012; 20:679-686.

47. Ghisoli M, Barve M, Schneider R, Mennel R, Lenarsky C, Wallraven G, Pappen BO, LaNoue J, Kumar P, Nemunaitis D, Roth A, Nemunaitis J, Whiting S, et al. Pilot Trial of FANG Immunotherapy in Ewing's Sarcoma. Mol Ther. 2015; 23:1103-1109.

48. Nemunaitis J, Barve M, Orr D, Kuhn J, Magee M, Lamont J, Bedell C, Wallraven G, Pappen BO, Roth A, Horvath S, Nemunaitis D, Kumar P, et al. Summary of bi-shRNA/ GM-CSF augmented autologous tumor cell immunotherapy (FANG) in advanced cancer of the liver. Oncology. 2014; 87:21-29.

49. Hinson AR, Jones R, Crose LE, Belyea BC, Barr FG and Linardic CM. Human rhabdomyosarcoma cell lines for rhabdomyosarcoma research: utility and pitfalls. Front Oncol. 2013; 3:183.

50. Häcker S, Dittrich A, Mohr A, Schweitzer T, Rutkowski S, Krauss J, Debatin K-M and Fulda S. Histone deacetylase inhibitors cooperate with IFN-gamma to restore caspase-8 expression and overcome TRAIL resistance in cancers with silencing of caspase-8. Oncogene. 2009; 28:3097-3110. 